\title{
The Structural Characteristics of Lightweight Aggregate Concrete Beams
}

\author{
Sajjad abdulameer badar \\ Civil Engineering department, Engineering College, University of Kerbala, Kerbala, Iraq \\ ensajjad52@gmail.com \\ Laith Shakir Rasheed \\ Civil Engineering department, Engineering College, University of Kerbala, Kerbala, Iraq \\ laith.alqarawee@uokerbala
}

Shakir Ahmed Salih

Civil Engineering department, University of Technology, Baghdad, Iraq

professorshakir@yahoo.com

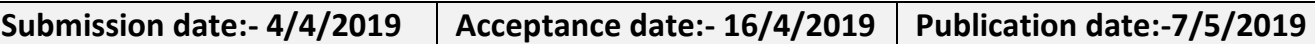

\begin{abstract}
:
This paper aims to investigate the structural behavior of reinforced lightweight concrete beams. Attapulgite aggregate and crushed clay brick aggregate were used as coarse lightweight aggregate to produce structural lightweight aggregate concrete with $25 \mathrm{Mpa}$ and 43.6 Mpa cube compressive strength and 1805 $\mathrm{Kg} / \mathrm{m}^{3}$ and $1977 \mathrm{Kg} / \mathrm{m}^{3}$ oven dry density respectively. The result of reinforced lightweight concrete beams compared with reinforced normal weight concrete beams, which have 50.5 Mpa cylinder compressive strength and $2317 \mathrm{Kg} / \mathrm{m}^{3}$ oven dry density. For each type of concrete two reinforced concrete beams with (1200 mm length $\times 180 \mathrm{~mm}$ height $\times 140 \mathrm{~mm}$ width), one of them tested under symmetrical two-points load STPL $(\mathrm{a} / \mathrm{d}=2.2)$ and another one tested under one-point load OPL $(\mathrm{a} / \mathrm{d}=3.3)$ at 28 days. The experimental program shows that a structural lightweight aggregate concrete can be produced by using Attapulgite aggregate with $25 \mathrm{MPa}$ cube compressive strength and $1805 \mathrm{Kg} / \mathrm{m}^{3}$ oven dry density and by using crushed clay brick aggregate with $43.6 \mathrm{MPa}$ cube compressive strength and $1977 \mathrm{Kg} / \mathrm{m}^{3}$ oven dry density. The weight of Attapulgite aggregate concrete and crushed clay bricks aggregate concrete beam specimens were lower than normal weight aggregate concrete beams by about $20.56 \%$ and $13.65 \%$ respectively at 28 days. As for the ultimate load capacities of beam specimens, the ultimate load of Attapulgite aggregate concrete beams tested under STPL were lower than that of crushed clay bricks aggregate concrete beams and normal weight aggregate concrete beams by about $4.85 \%$ and $5 \%$ respectively. While the ultimate load capacities of reinforced Attapulgite concrete beams tested under OPL were lower than that of reinforced crushed clay bricks aggregate concrete beams and reinforced normal weight aggregate concrete beams by about $10.3 \%$ and $10.5 \%$ respectively. Finally, Attapulgite aggregate concrete and crushed clay bricks aggregate concrete showed ductility and toughness less than that of Normal weight aggregate concrete.
\end{abstract}

Keywords: Structural lightweight concrete, Concrete beams, Crushed bricks aggregate, Attapulgite aggregate.

Journal of University of Babylon for Engineering Sciences by University of Babylon is licensed under a Creative Commons Attribution 4.0 International License. 


\section{Introduction:}

One of the most important available construction materials in the world is reinforced concrete [1]. The composition of reinforced concrete consists of steel and concrete which is successfully used in infrastructure for decades. However, every material has advantages and disadvantages. One of the disadvantages of reinforced concrete is its high self-weight, where its density ranges between $2200 \mathrm{~kg} / \mathrm{m} 3$ to $2600 \mathrm{~kg} / \mathrm{m} 3$. Thus, high weights will be imposed on the building, especially on the foundations. Therefore, lightweight concrete can tackle this problem by reducing the weight of concrete [2]. The concrete industry today is the largest consumer of limited natural resources, such as water, sand, gravel and crushed rock[3]. It has been reported that the concrete industry will consume 8 to 12 billion tons of natural aggregates annually after 2010[4]. Construction by its very nature is not necessarily an environmentally-friendly activity,[5] and this industry has a significant environmental impact[6]. The best alternative to achieve sustainable development of the concrete industry is the use of waste and by-product materials instead of raw materials in the concrete mixture[7]. In this way, for a large number of applications in the civil and structural engineering sector, concrete can be considered an environmentally friendly and sustainable construction material, which can contribute to a better quality of life for all mankind[8]. lightweight aggregate concrete (LWAC) made of artificial LWAs such as expanded clay, slate, shale, or blast furnace slag, is a type of environmentallyfriendly material for the construction industry. The reasons include that lightweight concrete reduces the dead load of construction. However, it should be noted that the manufacture of a lightweight aggregate needs to a lot of energy. This energy comes from the burning of coal, and, recently, a major part is from the burning of combustible liquid waste products[9]. There are other resources for lightweight aggregate, namely natural lightweight aggregates, which do not require a significant energy demand in their preparation compared to artificial lightweight aggregates. Some of these aggregates can be provided from natural lightweight rocks. The use of solid wastes from industry, such as oil palm shell (OPS), in lightweight concretes will be more sustainable in the construction industry[10]. Lightweight concrete was successfully used in a variety of structures and for several years. The most important purpose for using lightweight concrete is to decrease the weight of the structures, which can reduces the costs of construction as the density of lightweight concretes is less than the density of normal weight concrete by about $20 \%$ [11].

For producing lightweight concrete there are three techniques as follow[12]:

1- No-Fines Concrete: The composition of lightweight concrete is consisting of normal weight coarse aggregate and cement.

2- Aerated Concrete: This concrete can be produced by entrap the air into the concrete to create the cellular structure with voids about $30 \%$ to $50 \%$.

3- Lightweight Aggregate Concrete: This concrete can be produced by replacing (partially or fully) the natural aggregate by lightweight aggregate.

\section{Experimental program}

\subsection{Materials}

In this work, Attapulgite and crushed clay bricks were used as lightweight coarse aggregate with normal weight aggregate. The cement used in all mixes was conforms to the Iraqi Specification No. $5 / 1984[13]$. In all mixes, natural sand (fine aggregate) of $0-4.75 \mathrm{~mm}$ with light and normal weight coarse aggregate of $4.75-19 \mathrm{~mm}$ were used. The sieve analysis of fine and coarse aggregates was performed in accordance with Iraqi Specification No. 45/1984[14] and ASTMC330-05[15] respectively. For comparison purpose, same sieve analysis was used for Attapulgite aggregate, crushed clay bricks aggregate and normal weight aggregate. Plate 1 shows Attapulgite coarse aggregate used through this work. High performance super plasticizing admixture was used to obtain good workability for the fresh concrete mixture. 


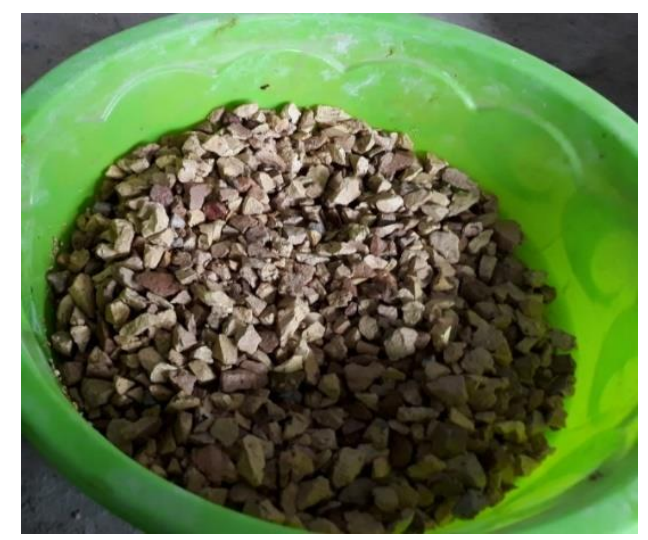

\section{Plate 1: Attapulgite coarse aggregate used}

Deformed steel bars $(12 \mathrm{~mm}, 6 \mathrm{~mm}$ and $5 \mathrm{~mm})$ in nominal diameter were used in this study as tensile reinforcement, compression reinforcement and shear reinforcement respectively. The tested specimens are conformed with ASTM A615M - 05a[16]. Where, the steel reinforcement $\varnothing 12 \mathrm{~mm}$ Conforming to the technical specifications required for steel (grade 60) while, steel reinforcement $\varnothing 6 \& 5 \mathrm{~mm}$ Conforming to the technical specifications required for steel (grade 40).

\subsection{Details of Reinforced Concrete Beam Models}

The experimental program consisted of testing six reinforced concrete rectangular beams. Three of these beams tested under symmetric two points load (STPL) as shown in figure (1) and the others tested under one-point load (OPL) as shown in figure (2), the cross section of beam illustrated in figure (3). All beams have the same dimensions; $140 \mathrm{~mm}$ width, $180 \mathrm{~mm}$ depth, $1200 \mathrm{~mm}$ length and 1050 effective span with $10 \mathrm{~mm}$ clear cover for each side. The reinforcement bars are cut to the desired length. After lubrication the molds of the beam sample, reinforcement bars are held carefully in their position inside the molds. The distribution of tensile reinforcement and shear reinforcement is constant for all types of beams. The beam specimens are simply supported as shown in figures (1) and (2).

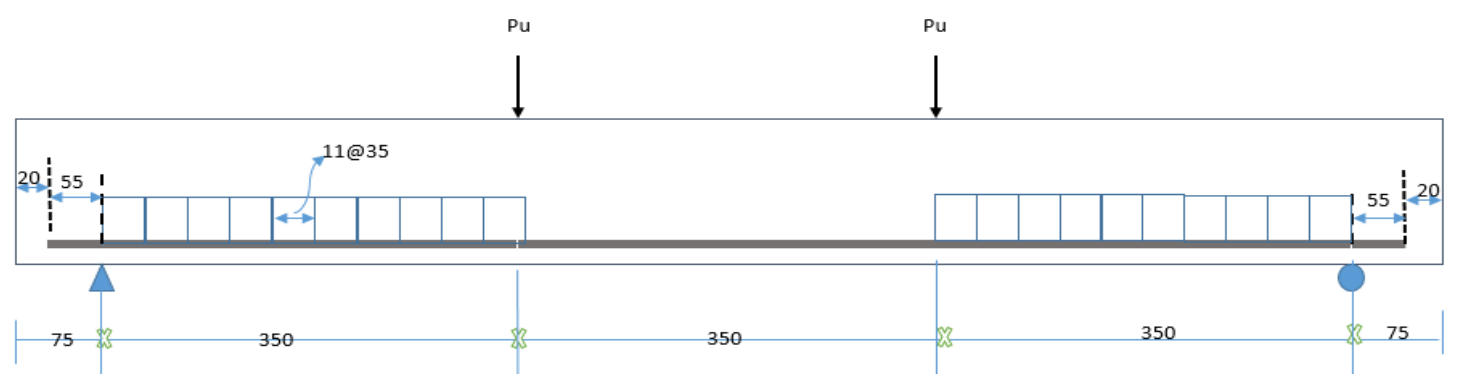

Figure 1: The longitudinal section of beam with symmetric two-point load

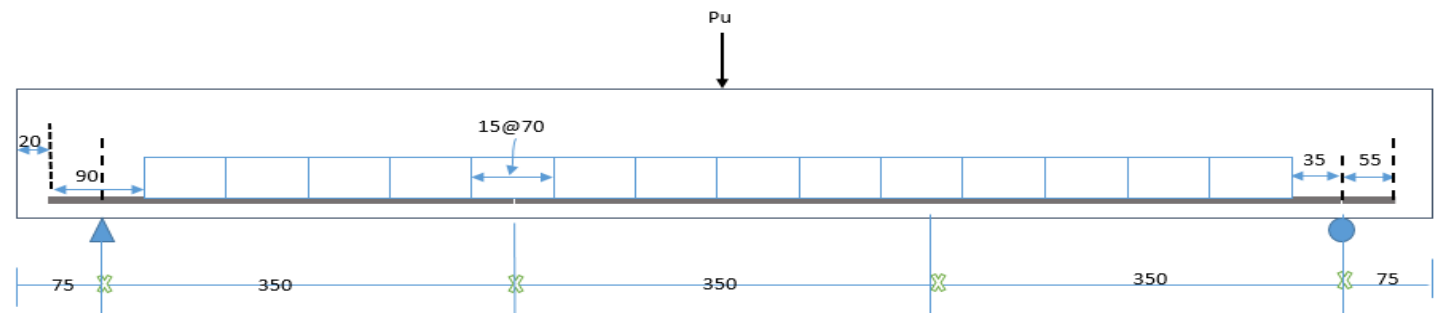

Figure 2: The longitudinal section of beam with one-point load 


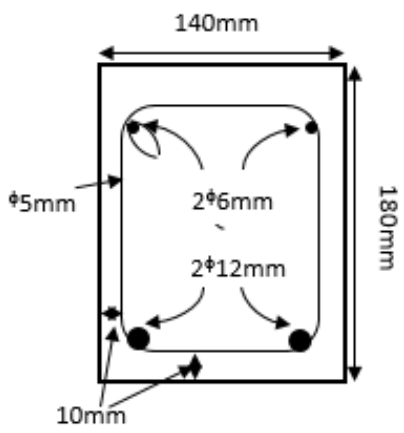

Figure 3: The cross section of beam

\subsection{Concrete Mix Design and Mixing Procedure}

In many codes structural lightweight aggregate concrete is defined as a concrete having oven dry density less than $2000 \mathrm{~kg} / \mathrm{m}^{3}$ and cylinder compressive strength more than $17 \mathrm{MPa}$ at 28 days. The mixes were designed and mixed in accordance with ACI committee 211.2-98 ${ }^{[17]}$ and ASTM C192/C192M-05 $5^{[18]}$ respectively. After many trials, one reference mix proportion was appointed in this study for different coarse aggregates used, except the super plasticizer content was changed with the aggregate type to achieve same workability as shown in table (1).

Table 1: concrete mix proportions for all specimens

\begin{tabular}{|c|c|c|c|c|c|c|c|c|}
\hline Mix & $\begin{array}{c}\text { Cement } \\
\mathrm{Kg} / \mathrm{m}^{3}\end{array}$ & $\begin{array}{c}\text { Dry fine } \\
\text { aggregate } \\
\mathrm{Kg} / \mathrm{m}^{\mathbf{3}}\end{array}$ & $\begin{array}{c}\text { Dry } \\
\text { coarse } \\
\text { aggregate } \\
\mathrm{Kg} / \mathrm{m}^{\mathbf{3}}\end{array}$ & $\begin{array}{c}\mathrm{W} / \mathrm{C} \\
\%\end{array}$ & $\begin{array}{c}\text { Plasticizer } \\
\%\end{array}$ & $\begin{array}{c}\text { Slump } \\
\mathrm{mm}\end{array}$ & $\begin{array}{c}\text { Cube } \\
\text { compressive } \\
\text { strength } \\
\mathrm{Mpa}\end{array}$ & $\begin{array}{c}\text { Oven } \\
\text { Dry } \\
\text { Density } \\
\mathrm{Kg} / \mathrm{m}^{\mathbf{3}}\end{array}$ \\
\hline $\begin{array}{c}\text { Attapulgite } \\
\text { aggregate }\end{array}$ & 328 & 549.5 & 515.6 & 31.5 & 1.51 & 90 & 28 & 1745 \\
$\begin{array}{c}\text { crushed } \\
\text { clay bricks } \\
\text { aggregate }\end{array}$ & 328 & 549.5 & 515.6 & 31.5 & 1.27 & 90 & 37 & 1861 \\
$\begin{array}{c}\text { Normal } \\
\text { weight } \\
\text { aggregate }\end{array}$ & 328 & 549.5 & 515.6 & 31.5 & 0.7 & 90 & 48 & 2331 \\
\hline
\end{tabular}

\subsection{Supporting and Loading Condition}

Two rigid steel $\mathrm{W}$-sections designed as a supporting system and placed on the top face of the testing machine base. To achieve a simply supported condition for a beam, steel bar of $30 \mathrm{~mm}$ diameter was welded on the upper face of one of the supports and use movable steel bar on the other support with an effective span of $1050 \mathrm{~mm}$, as shown in plate 2 , the supports were located at $75 \mathrm{~mm}$ from the beam ends.

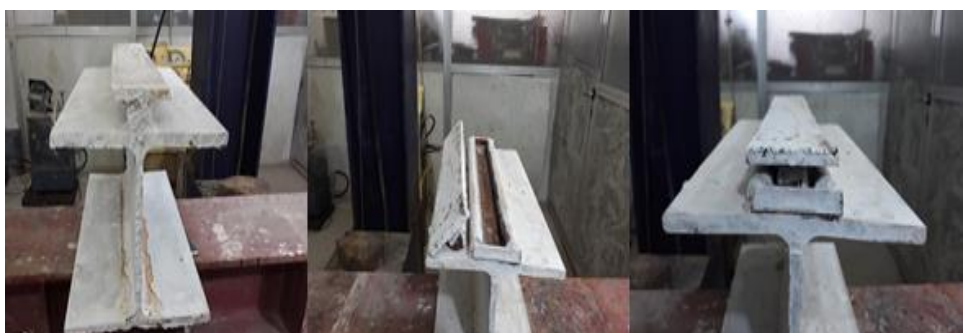

Plate 2: Supporting system of the tested beams 
All beam specimens were tested by using a universal testing machine with $1000 \mathrm{KN}$ capacity. This universal machine is available at the concrete Laboratory of Civil Engineering Department at Kerbala University. The deflection was measured by a LVDT of $100 \mathrm{~mm}$ capacity. One vertical LVDT was used at the center point of the beam specimens as shown in plate 3 .

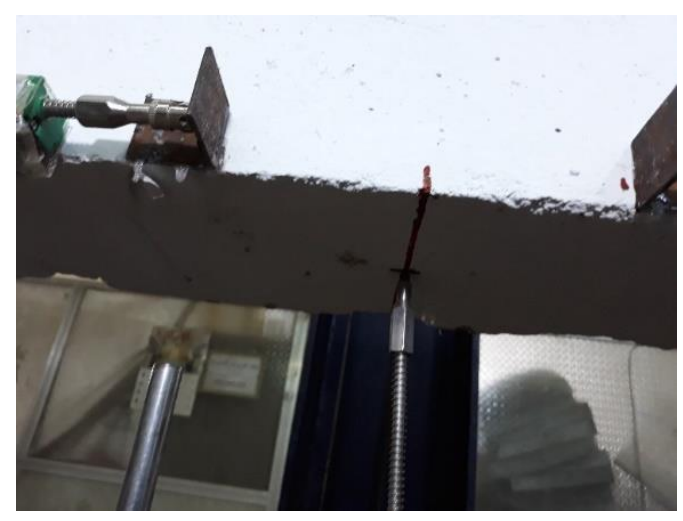

\section{Plate 3: LVDT used to measure the vertical deflection}

\section{Experimental Results}

\subsection{General behavior}

All concrete beams tested under same conditions. The deformation of beams was within the elastic ranges at an early stage of loading. When the applied load increased, the cracks start to appear at the tension face of beams, the number of cracks increase and the cracks become wider and moved upwards. As expected, the failure of all beams was a flexural failure as shown in plates 4 to 9 . For the beams tested under STPL $(\mathrm{a} / \mathrm{d}=2.2)$, the concrete crushing in compression face at final stage of loading. The recorded ultimate load, deflection and failure mode are presented in Table 2 for beam specimens tested under (STPL) and (OPL).

Table 2: Results of beam specimens tested under (STPL) and (OPL)

\begin{tabular}{|c|c|c|c|c|}
\hline $\begin{array}{c}\text { Beam } \\
\text { symbol }\end{array}$ & $\mathbf{( a / d )}$ ratio & Ultimate load Wu KN & $\begin{array}{c}\text { Max. deflection } \\
\mathbf{m m}\end{array}$ & Failure mode \\
\hline A-1-28 & 3.3 & 77.4 & 8.093 & Flexural failure \\
\hline A-2-28 & 2.2 & 119.6 & 7.364 & $\begin{array}{c}\text { Flexural failure+ } \\
\text { Crushing }\end{array}$ \\
\hline B-1-28 & 3.3 & 86.3 & 9.329 & Flexural failure \\
\hline B-2-28 & 2.2 & 125.7 & 14.374 & $\begin{array}{c}\text { Flexural failure+ } \\
\text { Crushing }\end{array}$ \\
\hline N-1-28 & 3.3 & 86.5 & 10.020 & Flexural failure \\
\hline N-2-28 & 2.2 & 125.9 & 17.137 & $\begin{array}{c}\text { Flexural failure+ } \\
\text { Crushing }\end{array}$ \\
\hline
\end{tabular}




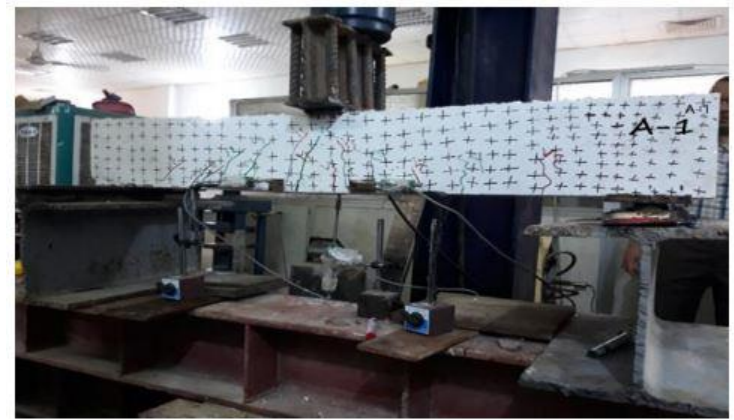

Plate 4: Cracks Patterns for A-1-28 beam specimen

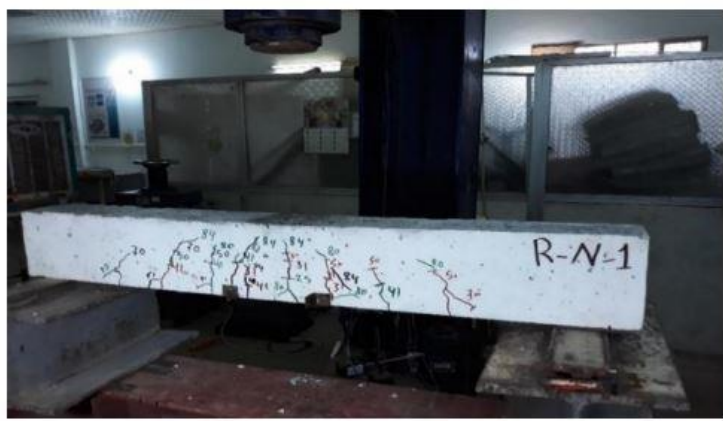

Plate 6: Cracks Patterns for N-1-28 beam specimen

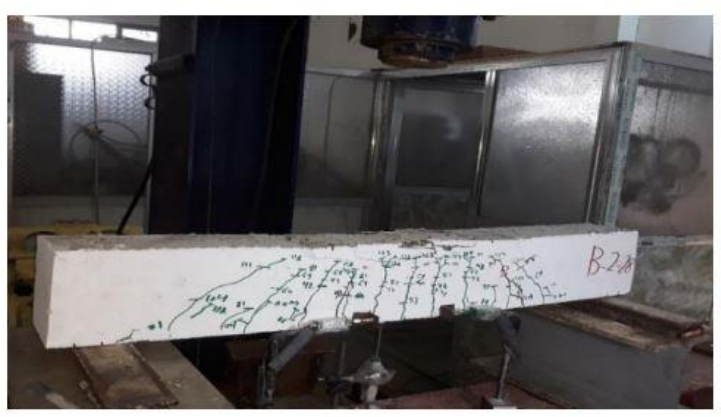

Plate 8: Cracks Patterns for B-2-28 beam specimen

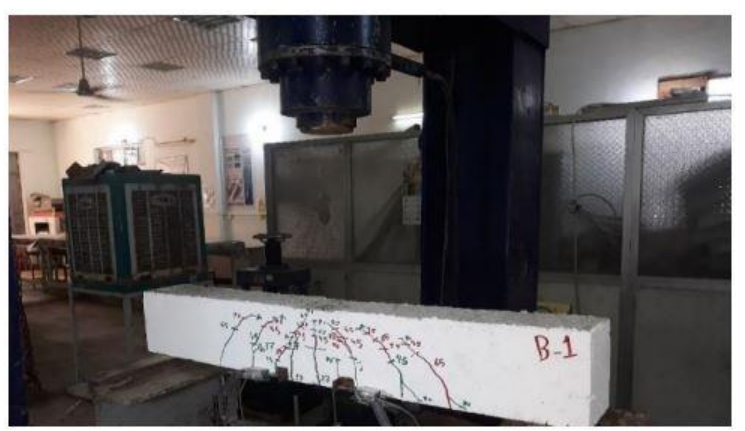

Plate 5: Cracks Patterns for B-1-28 beam specimens

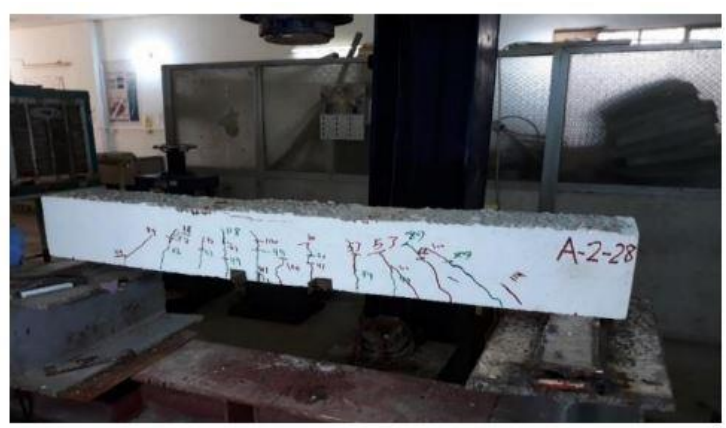

Plate 7: Cracks Patterns for A-2-28 beam specimen

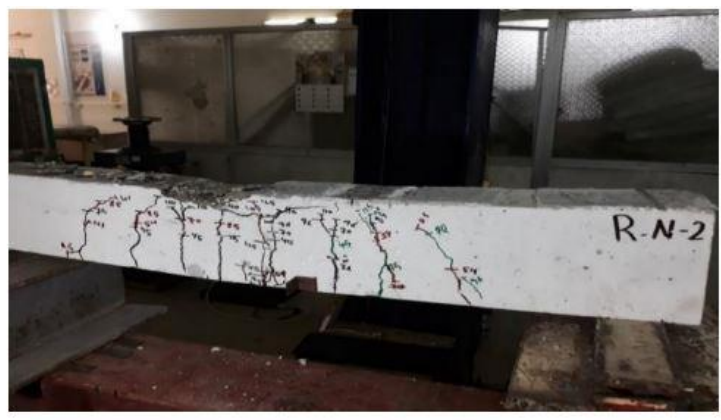

Plate 9: Cracks Patterns for N-2-28 beam specimen

\subsection{Ultimate Load}

The ultimate failure load for beam specimens tested under (STPL) and (OPL) was greater than the design load.

Study No.1: It is observed that, when the concrete compressive strength increases, the ultimate load is significantly increased. Therefore, using Attapulgite aggregate concrete instead of crushed clay bricks aggregate concrete and normal weight aggregate concrete causes decrease in ultimate load as shown in figure (4) but it is still within the requirements of structural concrete, the decrease in ultimate load is accompanied by a reduction in saturated surface dry density of reinforced concrete beams as shown in figure (5). 


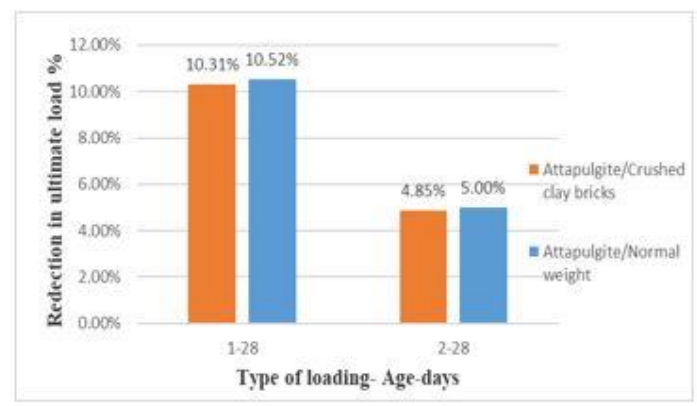

Figure 4: Reduction in ultimate load of the tested beams

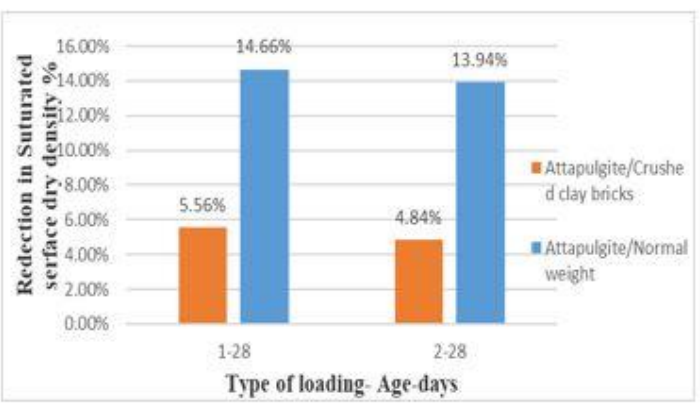

Figure 5: Reduction in saturated surface dry density of the tested beams

Study No.2: The effects of the variation of shear span to effective depth (a/d) ratio on the behavior of reinforced concrete beams is studied. The effect of $(\mathrm{a} / \mathrm{d})$ ratio on ultimate load for beams is presented in Table 2. Which illustrates that the ultimate load of these beams increase with increasing a/d ratio.

\subsection{Load-Deflection Curve}

One dial gages were placed at the center of beam in both $\mathrm{X}$ and Z-directions to measure the deflection. The ultimate deflection for beam specimens tested under (STPL) and (OPL) was greater than the design deflection.

Study No.1: It is observed that, in general the ultimate load and mid-span vertical deflection increased as the compressive strength of beam concrete increasing. Where, using Attapulgite aggregate concrete instead of crushed clay bricks aggregate concrete and normal weight aggregate concrete causes decrease in ultimate load and ultimate mid-span vertical deflection as shown in figures (6) and (7), the decrease in ultimate load and ultimate deflection is accompanied by a reduction in saturated surface dry density of reinforced concrete beam as shown previously in figure (5).

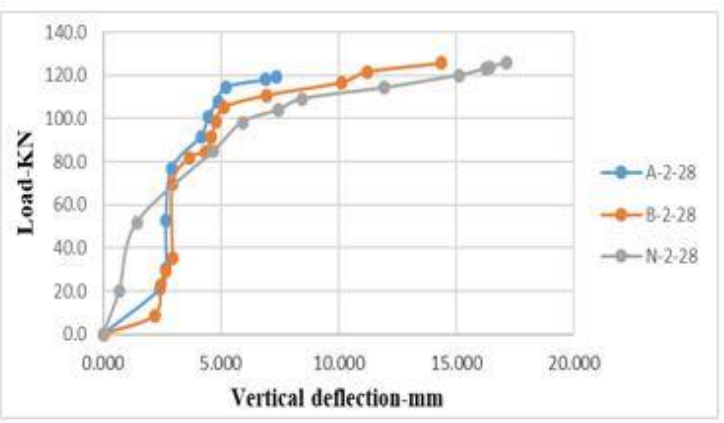

Figure 6: Load-deflection curve for beam specimens tested under STPL at 28 days

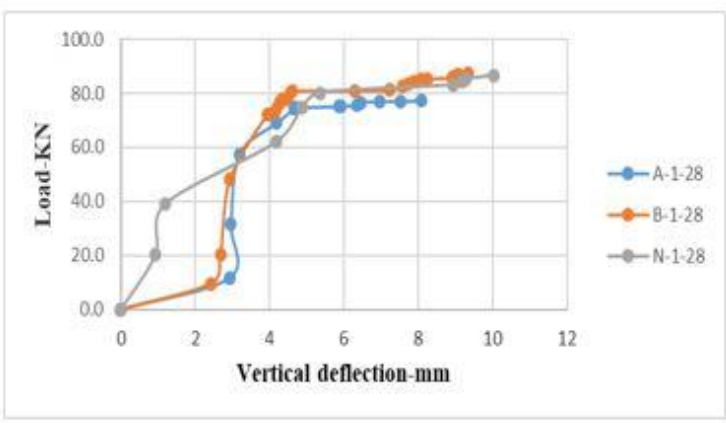

Figure 7: Load-deflection curve for beam specimens tested under OPL at 28 days

Study No.2: The effects of the variation of shear span to effective depth ratio $(\mathrm{a} / \mathrm{d})$ on the behavior of reinforced concrete beams is studied. For crushed clay brick aggregate concrete and normal weight aggregate concrete, the mid-span vertical deflection increased as the shear span/depth ratios (a/d) decrease. While, for Attapulgite aggregate concrete the mid-span vertical deflection increased as the shear span/depth ratios (a/d) increase. The effect of $(\mathrm{a} / \mathrm{d})$ ratio on ultimate load and mid-span vertical deflection for beams is presented in Table 2 and the behavior is shown in figures 8 to 10 . 


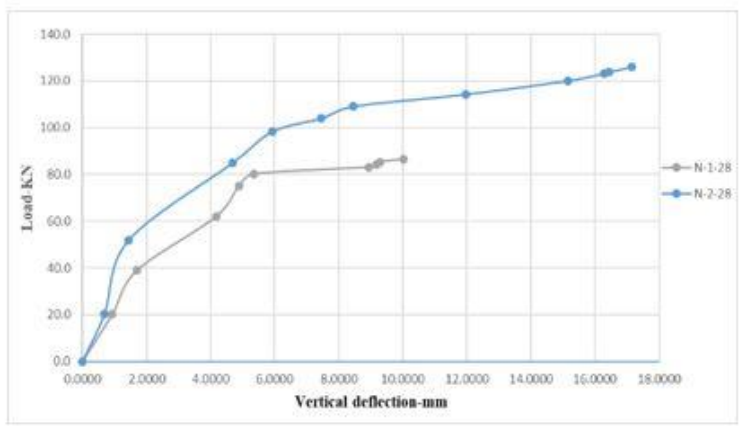

Figure 8: Load-deflection curve for normal weight aggregate concrete beams

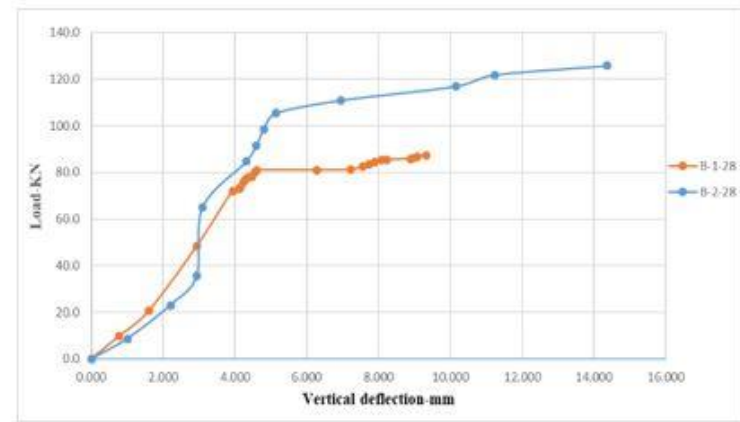

Figure 9: Load-deflection curve for crushed clay bricks aggregate concrete beams

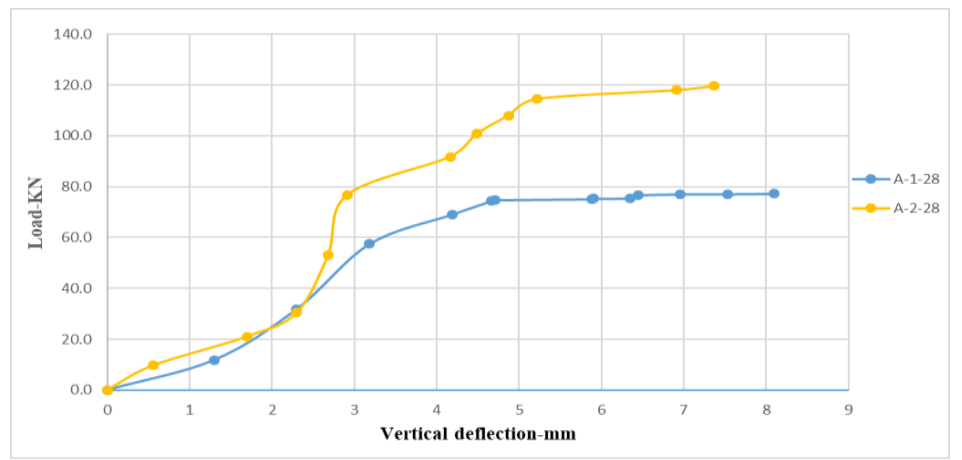

Figure 10: Load-deflection curve for Attapulgite aggregate concrete beams

\section{Conclusions}

Based on the overall results obtained from the experimental work, the following conclusions can be drawn:

1- It is possible to produce structural lightweight aggregate concrete based on Attapulgite aggregate and crushed clay brick aggregate.

2- For all beams, as it expected one mode of failure appeared which can be classified as flexural failure.

3- The weight of Attapulgite aggregate concrete and crushed clay bricks aggregate concrete beam specimens were lower than normal weight aggregate concrete beams by about $20.56 \%$ and $13.65 \%$ respectively at 28 days.

4- The ultimate load of beam specimens reduced when using Attapulgite aggregate concrete instead of crushed clay bricks aggregate concrete and normal weight aggregate concrete by about $(10.31 \%$ \& $10.52 \%)$ and $(4.85 \% \& 5 \%)$ for beams tested under one-point and two-points load respectively, but it is still within the structural requirements, the decrease in ultimate load is accompanied by a reduction in saturated surface dry density of reinforced concrete beams.

5- The ultimate load of beam specimens increases when $(\mathrm{a} / \mathrm{d})$ ratio decrease.

6- The mid-span vertical deflection of beam specimens reduced when using Attapulgite aggregate concrete instead of crushed clay bricks aggregate concrete and normal weight aggregate concrete by about $(13.2 \%$ $\& 19.2 \%)$ and $(48.7 \% \& 57 \%)$ for beams tested under one-point and two-point concentrated load respectively.

7- For crushed clay brick aggregate concrete and normal weight aggregate concrete, the mid-span vertical deflection increased as the shear span/depth ratios $(\mathrm{a} / \mathrm{d})$ decrease. While, for Attapulgite aggregate concrete the mid-span vertical deflection increased as the shear span/depth ratios (a/d) increase 


\section{CONFLICT OF INTERESTS.}

- There are no conflicts of interest.

\section{References}

[1] Winter G., "Design of Concrete Structures", McGraw-Hill Book Company, Thirteen Edition, 2004.

[2] Neville A. M., "Properties of Concrete", Longman Group Limited, Fifth Edition, 2011.

[3] Mefteh H., et al., "Influence of moisture conditioning of recycled aggregates on the properties of fresh and hardened concrete", Journal of cleaner production, 54, 2013.

[4]Tu T., Chen Y., and Hwang C., "Properties of HPC with recycled aggregates", Cement and concrete research, 36(5): p. 943-950, 2006.

[5]Tam V., "Comparing the implementation of concrete recycling in the Australian and Japanese construction industries", Journal of Cleaner production, 17(7): p. 688-702, 2009.

[6]Pelisser F., et al., "Lightweight concrete production with low Portland cement consumption", Journal of Cleaner Production, 23(1): p. 68-74, 2012.

[7]Pelisser F., et al., "Concrete made with recycled tire rubber: effect of alkaline activation and silica fume addition", Journal of Cleaner Production, 19(6-7): p. 757-763, 2011.

[8]Swamy R.N.,"Design for sustainable development of concrete construction", in Proceedings of the Fourth International Structural Engineering and Construction Conference (ISEC 4), Taylor \& Francis Ltd England, 2007.

[9]Bremner T.W.,"Environmental aspects of concrete: problems and solutions", in All-Russian Conference on Concrete and Reinforced Concrete, 2001.

[10]Shafigh P., et al., "Structural lightweight aggregate concrete using two types of waste from the palm oil industry as aggregate", Journal of Cleaner Production, 80: p. 187-196, 2014.

[11]Kivrak S., et al., "An Economic Perspective of Advantages of Using Lightweight Concrete in Construction", 31st Conference on our world in concrete \& structures, 2006.

[12]Newman J. and and Owen P., "Properties of Lightweight Concrete, Advanced Concrete Technology" Butterworth-Heinemann, 2003.

$$
\text { [13] [13] النوعية، بغدة القياسية العر اقية رقم } 5 \text { لسنة 1984، "السمنت البورتلاندي"، الجهاز المركزي اللتقييس المواصفة القياسية العر اقية والسيطرة }
$$

[15]ASTM Designation C330-05, "Lightweight Aggregates for Structural Concrete", nnual Book of ASTM Standards, American Society for Testing and Materials \& Design, 2005.

[16]ASTM A 615/A615M-05a, "Standard Specification for Deformed and Plain Billet-Steel Bars for Concrete Reinforcement”, ASTM Committee A01 on Steel, Stainless Steel, and Related Alloys, West Conshohocken, PA 1942-2959, United States, 5 pp, 2005.

[17]ACI Committee 211, "Standard Practice for Selecting Proportion for Structural Lightweight Concrete", (ACI 211-2-98),ACI Manual of Concrete Practice, Part 1, 2004.

[18]ASTM C 192/C 192M-05, "Standard Practice for Making and Curing Concrete Test Specimens in the Laboratory", Annual Book of ASTM Standards, American Society for Testing and Materials, pp. 1-8, 2005 . 
Journal of University of Babylon for Engineering Sciences, Vol. (27), No. (2): 2019.

\title{
الخصائص الانشائية للأعتاب الخرسانية خفيفة الوزن
}

\author{
سجاد عبد الامير بلر \\ قسم الهندسة المدنية، كلية الهندسة، جامعة كربلاء، كربلاء، العراق \\ ensajjad52@gmail.com \\ ليث شاكر رشيد \\ قسم الهندسة الددنية، كلية الهندسة، جامعة كربلاء، كربلاء، العراق \\ laith.alqarawee@uokerbala \\ شاكر أحمد صالح \\ قسم الهندسة المدنية، كلية الهندسة، الجامعة التكنولوجية، بغد/د، العراق \\ professorshakir@yahoo.com
}

الخلاصة:

تهدف هذه الدراسة الي دراسة السلوك الانثائي للعنبات الخرسانية المسلحة الخفيفية الوزن. تم استخدام ركام الاتبولكايت وركام

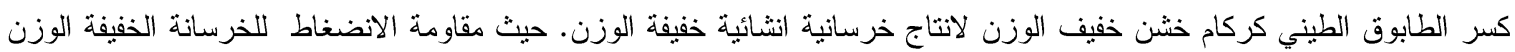
الحاوية على ركام الاتبولكايت و ركام كسر الطابوق الطيني تساوي 25 و 43.6 ميغاباسكال على التو الي. في حين الكثافة الجافة للخرسانة

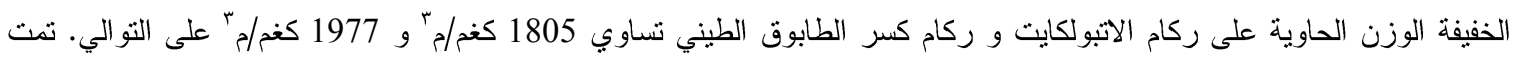
مقارنة نتائج فحص العتبات الخرسانية المسلحة الخفيفة الوزن مع نتائج العتبات الخرسانية المسلحة الاعتبادية الوزن، علما ان مقاومة

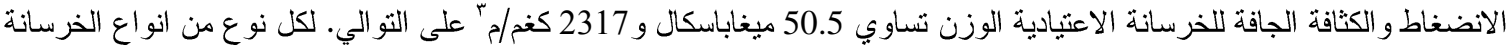

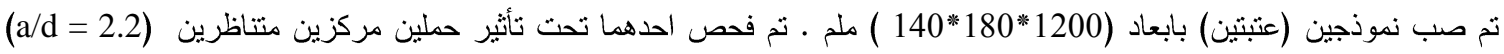

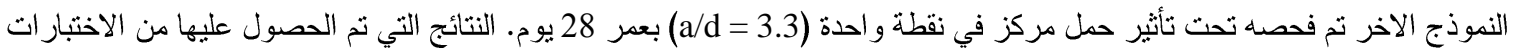
توضح امكانية انتاج خرسانة انثائية خفيفة الوزن بأستخدام الاتبولكايت وكسر الطابوق الطيني كركام خشن. حيث الكثافة الجافة للخرسانة

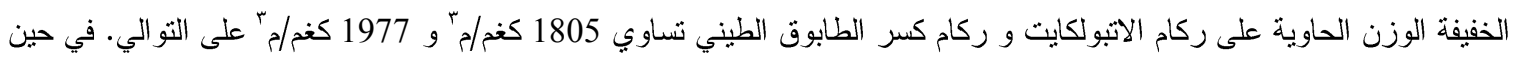
مقاومة الانضغاط للخرسانة الخفيفة الوزن الحاوية على ركام الاتبولكايت و ركام كسر الطابوق الطيني تساوي 25 و 43.6 ميغاباسكال على التوالي. اما بالنسبة للتحمل الاقصى للعتبات فان العتبات الخرسانية المفحوصة تحت تأثنز حملين مركزين متتاظرين فان ت تحملها

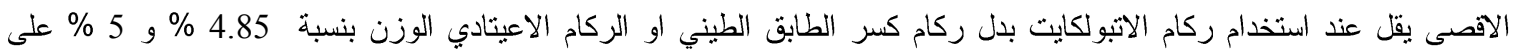
التو الي. في حين العتبات الخرسانية الدفحوصة تحت تأثر حمل مركز في نقطة واحدة فان تحملها الاقصى يقل عند استخدام ركام الاتبولكايت بدل ركام كسر الطابق الطيني او الركام الاعيتادي الوزن بنسبة 10.3 \% و 10.5 \% على الإنى التو الي. كذللك اوضحت نتائج

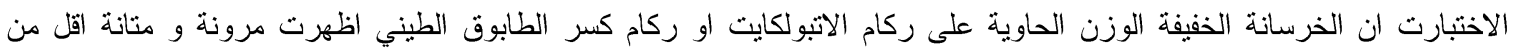

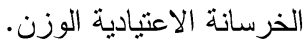
الكلمات الداله: الخرسانية الانثائية الخفيفة الوزن، عتبات خرسانية، ركام كسر الطابوق الطيني، ركام الاتبولكايث. 